\title{
MEDIA CHOICE AND THE POLARIZATION OF PUBLIC OPINION ABOUT COVID-19 IN BRAZIL
}

Elección de Medios de Comunicación y la Polarización de la Opinión Pública sobre la Covid-19 en Brasil

Preferências por Meios de Comunicação e a Polarização das Opiniões sobre a Covid-19 no Brasil

\section{FREDERICO BATISTA PEREIRA (1) fbatist1@uncc.edu ${ }^{1}$}

\section{FELIPE NUNES (1) felipe.nunes@quaest.com.br 2}

\author{
1 University of North Carolina at Charlotte \\ 2 Universidade Federal de Minas Gerais
}

\section{Keywords: media choice; public opinion; COVID-19; \\ Brazil; \\ Bolsonaro}

\begin{abstract}
Brazil is one of the countries most affected by the Covid-19 pandemic. Yet, while rates of contagion and deaths increase over time, polls show that opinions about the pandemic become less concerned about the virus and less supportive of mitigation measures. According to observers, a key factor in this process is President Bolsonaro's denialist stance. In this paper, we show that patterns of media choice help explain how Bolsonaro influences public opinion over time. Using three online surveys conducted at different stages of the pandemic, we show that the divergence in views about the pandemic is driven largely by Bolsonaro supporters who prefer to consume news online. The findings have implications not just for understanding the politicization of the pandemic in Brazil, but also for the relationship between populism and mass communications in the social media era.
\end{abstract}




\section{Palabras clave:}

elección

de medios;

opinión pública;

COVID-19;

Brasil;

Bolsonaro

\section{Resumen}

Brasil es uno de los países más afectados por la pandemia de Covid-19. Sin embargo, aunque las tasas de contagio y muertes aumentan con el tiempo, las encuestas muestran que las opiniones sobre la pandemia evidencian una menor preocupación al respecto y un menor apoyo a las medidas de mitigación. Según los observadores, un factor clave en este proceso es la postura negacionista del presidente Jair Bolsonaro. En este artículo, mostramos qué patrones de elección de medios de comunicación para obtener información ayudan a explicar cómo Bolsonaro influye en la opinión pública a lo largo del tiempo. Utilizando tres encuestas online realizadas en diferentes etapas de la pandemia, mostramos que el desacuerdo en las opiniones sobre la pandemia es impulsado en gran parte por los partidarios de Bolsonaro que prefieren consumir noticias en internet. Los resultados tienen implicaciones no solo para comprender la politización de la pandemia en Brasil, sino también para la relación entre populismo y medios de comunicación en la era de las redes sociales.

Palavras-chave:

imprensa; opinião pública; COVID-19; Brasil; Bolsonaro

\section{Resumo}

O Brasil é um dos países mais afetados pela pandemia da Covid-19. No entanto, enquanto as taxas de contágio e mortes aumentam ao longo do tempo, pesquisas mostram que as opiniões sobre a pandemia se tornam menos preocupadas com o vírus e menos favoráveis às medidas de mitigação. Segundo observadores, o fator chave nesse processo é o negacionismo do Presidente Jair Bolsonaro. Neste artigo, mostramos que padrões de preferências por meios de comunicação ajudam a explicar como Bolsonaro influencia a opinião pública ao longo do período. Utilizando três pesquisas de opinião online conduzidas ao longo da pandemia, mostramos que a divergência em visões sobre o problema ocorre principalmente devido aos apoiadores de Bolsonaro que preferem consumir notícias na internet. Os resultados trazem implicações não apenas para entendermos a politização da pandemia no Brasil, mas também a relação entre populismo e comunicação de massa na era das redes sociais.

\section{INTRODUCTION}

Brazil is one of the countries most affected by the Covid-19 epidemic. The consequences of the outbreak include a high death-toll, the subsequent collapse of the healthcare system, and a long-term economic recession. Yet, the dynamics of Brazilian public opinion about the outbreak are somewhat disconnected from those consequences. While polls show that the public expressed high levels of concern and support for social distancing policies in the initial stages of the outbreak, later surveys show decreasing levels of concern, as well as more politically divided views on social distancing (Datafolha, 2020b). That is, while the death toll rapidly increases in the country, a portion of the public becomes less supportive of the measures that are recommended to mitigate the problem.

According to observers and scholars, a key component in the explanation of the puzzle of public opinion about Covid-19 in Brazil is President Jair Bolsonaro. 
After a brief period in March in which the Health Cabinet held the protagonist role in dealing with the pandemic, Bolsonaro escalated a denialist rhetoric that consisted in trivializing the health consequences of the outbreak, spreading misinformation, blaming state governors for the economic aspects of the crises, and attacking the media (Vieira and Matos, 2020). According to studies, the President's actions stimulated defection with respect to collective efforts to mitigate the pandemic, especially among his supporters (Ajzenman et al., 2020; Calvo and Ventura, 2020). The President also defied what seemed to be a broad consensus among elites and public in Brazil about the gravity of the pandemic, since most governors and mayors had a central role in designing and implementing policies to address the problem (Rocha et al., 2020). Congress responded quickly by approving an Emergency Aid program for certain occupational categories in early April, which Bolsonaro took a month to sign after vetoing significant portions of the bill. The Federal Ministry of Health coordinated with the judiciary to adjust the legal framework for the implementation of social distancing policies and the expansion of healthcare infrastructure (Croda et al., 2020). Finally, mainstream media coverage, particularly on $\mathrm{TV}$, was intense and informative from the beginning, following the coverage from countries where the outbreak started sooner. As evidence of that, polls show that the public was highly aware of the issue from the early stages of the outbreak (Datafolha, 2020a).

This paper explores the main mechanism by which Bolsonaro defied a broad consensus and shifted his supporters' perceptions about the Covid-19 outbreak. The President challenged an existing mainstream media cartel on mass communications in Brazil and used social media to spread his message among his supporters. Since online environments give users more discretion to choose news content relative to TV and radio, supporters of the President were able to avoid the more uniform health-focused coverage of Brazilian mainstream media, and resort to the President's online information brokers. Using data from three online surveys collected at different stages of the pandemic in Brazil (March, April, and June), we show that decreases in concern and support for policies, as well as political polarization, became more pronounced over time among respondents who relied on internet sources for news consumption. The findings highlight the role of online environments as communication structures that favor populists (Waisbord and Amado, 2017), which can be particularly problematic during crises that require institutional trust and cooperation.

\section{POPULISM, MEDIA CHOICE, AND PUBLIC OPINION}

Brazilian President Jair Bolsonaro fits a broader pattern of emerging populist leaders around the globe. Populism is defined as the ideology that proposes 
a Manichean division of society between the "pure people" and "corrupt elites" (Mudde and Rovira Kaltwasser, 2017, 5-6). These features are defining elements of Bolsonaro's rhetoric, especially in comparison to other recent Brazilian presidents (Tamaki and Fuks, 2020). The populist rhetoric, combined with an ability to capitalize on dissatisfactions with crime, corruption, and the economy, fostered Bolsonarismo as a powerful right-wing conservative force that shaped public opinion in Brazil after 2018 (Rennó, 2020; do Amaral, 2020). Notably, Bolsonaro's success corroborates the notion of populism as a strategy that can be effective under specific circumstances (Weyland, 2001).

One of the central aspects in populism as a strategy is the attempt to influence large sectors of public opinion through mass communication. Influencing public opinion about which side to take on new and old issues is an important component of leaders' strategies, especially in presidential systems (Ragsdale, 1984; Mondak, 1993; Rottinghaus, 2009). Moreover, presidential influence can take on at least two forms, as it can either have the effect of homogenizing (persuasion) or dividing (polarization) opinions about political issues. As Cohen (2015) shows, presidents are more likely to exert persuasion when they attempt to play the role of national rather than party leaders. When their rhetoric is partisan and divisive, they will likely polarize opinions between supporters and opposition. Therefore, as rhetoric is a core strategic element of populism, the interaction between presidential influence and the media environment will shape the type of influence that populists exert on public opinion.

Television and radio were central components of politicians' strategies of mass communication in earlier populist waves. The extent to which populist candidates and politicians were able to access television and radio to spread their messages was determinant of their electoral success in the past (Weyland, 1998; Boas, 2005). Moreover, access to television and radio was usually combined with rhetorical strategies that sought to mobilize large portions of the electorate (Betz, 2019). In this sense, earlier populist waves displayed rhetoric to exert persuasion rather than polarization. However, the logic of interaction between mainstream media and politics no longer tells a complete story about the phenomenon around the world. The consistent growth of internet access and alternative online content has changed the dynamics of distribution of information (Mounk, 2018). Mass communication online involves fewer gatekeepers to news content and allows users to become broadcasters of information. Given the low costs and potentially high reach of mass communication online, politicians - and populists in particular must adapt their political strategies to the new informational market.

The consistent growth of internet access and alternative online content increases the ability of a substantive portion of the public to choose the information they will be exposed to online (Prior, 2005). Therefore, increasing media choice denotes that politicians must communicate with voters through different 
informational environments. While news and message consumption on TV, radio, and newspapers is more passive and homogenous, online consumers can actively select the content they are exposed to (Stroud, 2008, 2010).

The change in the informational environments of democracies ultimately reshapes the logic of populism. The growth of online mass communications increases the power of a substantive portion of the public to choose the information they will be exposed to online. Prior (2005) defines this process as the increase in media choice, that is, the extent to which viewers can select the content to which they will be exposed in the media. Based on this perspective, the standard structure of broadcasting in the earlier stages of populism can be defined as a low-choice environment, since information (news) was distributed by few television stations with high reach. Consequently, most people did not have many options with respect to learning new information about political events and issues. The internet era puts citizens in a high-choice media environment where they can select the news content based on their prior preferences. The increased access to internet services and the proliferation of news sources online means that audiences are now fragmented and politicians are no longer as likely to reach large portions of the public as the they were before. Moreover, high choice environments with fewer gatekeepers are also characterized by lower adherence to standard journalistic practices of vetting and editing (Mclntyre, 2018). Most notably, the increase in media choice and fragmentation of audiences online reduces the aggregate media effects of mainstream types of communication, especially television (Bennett and lyengar, 2008). Therefore, in this new structure of mass communications, populists are less able to reach a large share of the public and have weaker incentives to invest in using mainstream media to spread their message, unless they can have full control of a concentrated media market. Once unable to occupy mainstream media, populists have incentives to attempt to capture the attention and create niches of support through online "bubbles", that is, clusters of individuals who are highly selective of similar online content (Bakshy et al., 2015; Barberá et al., 2015). The increased media choice in online environments changes the dynamics of presidential influence from persuasive to polarizing. In this sense, online environments and social media provide a different communication structure that suits populists that attempt to influence part of the electorate, but not all of it (Waisbord and Amado, 2017).

Hence, while online media environments do not necessarily have a direct effect on opinions about new issues, they boost the effect of existing political allegiances and preferences in opinion formation. Online media environments polarize the public on new salient issues, and therefore incentivize communicators who benefit from polarization to invest their time and resources in promoting dissent online. In this sense, features such as selective exposure and online "bubbles" boost certain populist threats to democracy, since they allow populists to produce and maintain dissent and make it "hard to establish cooperative dialogue and reaching 
agreements" (Rovira Kaltwasser, 2017, 621). Moreover, those effects are particularly problematic during health crises. Pandemics and epidemics require largescale collective efforts of disease mitigation that create cooperation problems, since compliance in social distancing practices imply that individuals can often be reluctant to pay the costs of such practices, while benefitting from the outcomes produced by the group's cooperation (Reluga, 2010). Moreover, defection even by a small number of individuals can limit the effectiveness of mitigation efforts and harm the collectivity (Salathé and Bonhoeffer, 2008; Sahneh et al., 2012). All in all, dissent can be costly during health crises, but politically beneficial for political actors who gain from undermining institutions.

On the other hand, the context of pandemics may provide opportunities for strengthening the democratic institutions that populists seek to undermine. By imposing a demand for dialogue and cooperation, while also raising the salience of experts (Baekkeskov and Rubin, 2014), large-scale health crises require the building of cooperative institutional practices that populists often attempt to break. The evidence from the Covid-19 outbreak in Europe suggests that politicians who lead or join cooperative efforts of mitigation tend to gain popularity, as well as the experts and institutions that cooperate in addressing the issue (Bol et al., 2020). Moreover, the convergence in mainstream media coverage during such crises tends to make it more similar to public broadcasting, which has larger media effects than conventional media (Fraile and lyengar, 2014). While those circumstances can boost civic awareness and help institutional cooperation, they also create strong incentives for populist leaders to use the online environment as means to sabotage such process. Therefore, while the new polarizing logic of populism on social media is not specific to situations of crises, it likely becomes stronger under those circumstances.

\section{THE POLARIZATION OF COVID-19 IN BRAZIL}

Online and telephone-based public opinion polls from the early stages of the pandemic in March show overwhelming levels of concern and support for largescale measures to mitigate the spread of the virus in Brazil. Surprisingly, later polls show that, while the number of cases and deaths increased at alarming rates, levels of concern about the virus and support for mitigation efforts had decreased (Datafolha, 2020a).

The same polls also show that Brazilians were highly aware of the epidemic from the early stages of the outbreak (Datafolha, 2020a). Mainstream media coverage about the pandemic was intense from the beginning, due to the influence of the coverage from countries where the outbreak started sooner. During the first months of the pandemic, the main television networks promoted major changes 
in their schedules, replacing daily hours of regular content with news coverage about the outbreak ${ }^{1}$. The content of Jornal Nacional, the prime-time news broadcast for the largest TV channel (Globo), focused almost exclusively on covering the pandemic, while leaving reduced time for other major events (Silva and Suzart, 2020). Also, the main national newspapers associated with TV networks also provided intense coverage of the outbreak, while emphasizing its sanitary consequences (Manchetômetro, 2020). Consequently, most Brazilians initially relied on mainstream media and did not trust information received online about the pandemic (Datafolha, 2020a). The early convergence of media coverage and public opinion highlights the potential effects of mainstream media in Brazil, especially television, as demonstrated by the scholarship (Boas, 2005; Porto, 2010; Mundim, 2012).

In late March, President Jair Bolsonaro defied the general trend of cooperation among media, institutions, and elites. Initially, with the Ministry of Health leading the coordination efforts, Bolsonaro's positions were less salient and reduced to isolated remarks that conveyed mixed signals. For instance, the President stated on March 7th that Brazilians should "rigorously follow the recommendations of experts," but days later said that the virus was "overblown" (March 9th)². Bolsonaro later changed his approach, with the turning point coming on March 24th, when he gave a 5-minute nationally televised address. The President repeated several of the earlier remarks and urged Brazilians to go back to "normality" to save the economy (Eisenhammer and Spring, 2020). Bolsonaro now combined the trivializing language of earlier remarks with explicit denial of the gravity of the pandemic, while also providing a counterframe to highlight the economic effects of the pandemic, stating that lockdowns would be more harmful than the outbreak itself. All in all, Bolsonaro's stance and framing of the pandemic emerged in sharp contrast with mainstream media (especially TV) coverage.

Given the predominantly health-related and cooperative framing of mainstream media coverage in the country, the general reaction to Bolsonaro's stance from public opinion was initially negative. As a response, Bolsonaro promoted recurring attacks against the press and gradually increased his efforts to spread his message (Waldron, 2020). Bolsonaro relied on the new structure of mass communications to counter the predominant narrative about the pandemic and spread his own among his supporters. The evidence about the online environment in Brazil shows that it is predominantly anti-democratic and low in rationality (Mendonça and Amaral, 2016; Massuchin et al., 2017; Mitozo et al., 2017). Another defining feature of that environment is widespread misinformation, which peaked during

1. See "Impactos da pandemia na televisão brasileira" (2021).

2. For the March $7^{\text {th }}$ statement, see Deutsche Welle (2020). For the March $9^{\text {th }}$ statement, see G1 (2020). 
the 2018 elections won by Bolsonaro (Machado et al., 2019; Resende et al., 2019; Rossini et al., 2020). Given Bolsonaro's anti-establishment and exclusionary populism (do Amaral, 2020; Rennó, 2020; Tamaki and Fuks, 2020), his electoral emergence and governing style rely heavily on the growth of social media as the means to reach and spread his message (Duque and Smith, 2019). With respect to the pandemic, the initial evidence shows that online environments were overwhelmed with misinformation campaigns after Bolsonaro escalated his denialist stance (Ricard and Medeiros, 2020). For instance, Galhardi et al. (2020) show that misinformation about the coronavirus outbreak in Brazil was primarily spread through private messaging apps (WhatsApp) and social media websites (Instagram and Facebook). Recuero and Soares (2020) show that sharing of misinformation about the pandemic on Twitter was strongly associated with messages of support for Bolsonaro and narratives consistent with his framing of the pandemic.

Bolsonaro's escalation in explicitly denying the gravity of the outbreak during late March affected public perceptions about the pandemic over time. Ajzenman et al. (2020) use cell phone location data to show that compliance with social distancing decreased more sharply after late March, especially in localities with larger support for the President. Calvo and Ventura (2020) show that social media messages had the potential to shape views about Covid-19. Finally, Storopoli et al. (2020) use original survey data to show that, while trust in the media is positively associated with Brazilians' willingness to engage in preventive behavior towards the outbreak, trust in the federal government displays the opposite relationship.

Scholars have yet to explore the direct connection between online environments - where Bolsonaro's narrative of the pandemic primarily spread - and the public's reaction to the events related to the pandemic. We propose that, given the predominantly pro-cooperation style of TV coverage during the first months of the pandemic, Bolsonaro's explicit denialist stance after late March affected his supporters primarily through online environments. Therefore, media choice moderates Bolsonaro's polarizing influence on public opinion after March. Moreover, since Bolsonaro's denialism was not immediate, especially in the earlier weeks of March, we expect to see no polarization in March and growing polarization (association between support for Bolsonaro and opinions about the pandemic) in later months. This divergence should be more prominent after March, and particularly among respondents who express preference for online news sources. Finally, as Bolsonaro provided an alternative narrative or frame about the pandemic by emphasizing that Brazilians should be more concerned about the economic than the health consequences of the outbreak, we expect that message to reach online news consumers more effectively than offline (TV) news consumers. We derive three specific hypotheses about the relationship between media choice, support for Bolsonaro, and attitudes towards the outbreak from this broader perspective: 
Hypothesis 1 (H1): Support for Bolsonaro is not associated with attitudes about the pandemic in March 2020, for either online or offline news consumers.

Hypothesis 2 (H2): Support for Bolsonaro decreases concern about and support for mitigation measures after March 2020, especially among online news consumers.

Hypothesis $3(\mathrm{H} 3)$ : Support for Bolsonaro and online news consumption increase acceptance of the economic frame of the pandemic as a national problem after March 2020.

\section{DATA}

The survey data comes from three online polls conducted by Quaest Pesquisa \& Estratégia, which has an online panel of approximately 150,000 people in about 2,000 Brazilian cities ${ }^{3}$. The surveys correspond to monthly polls conducted in March, April, and June, and have 1,000 respondents each ${ }^{4}$. The samples are nationally representative of the online population in terms of age, gender, and education ${ }^{5}$. The first poll was conducted between 19 and 23 of March, the second between 25 and 26 of April, and the third between 14 and 17 of June. The timing of the surveys fits well with the purposes of the paper, since the March poll was conducted during the early stages of the outbreak, before Bolsonaro's escalated his strategy of denying the seriousness of the outbreak and undermining mitigation efforts.

The dependent variables analyzed here are concern about the outbreak, opinions about large-scale policies to address the problem, and acceptance of the economic rather than health-related frame about the pandemic ${ }^{6}$. The measure of concern about the virus comes from a question asking respondents about how worried they were that they or someone they know could become infected by the virus. The average score of concern on the 0-1 scale drops from .89 in March to .83 in April and June. The measure of support for large-scale measures against the outbreak differs between the March and later rounds, so the comparisons must be taken with caution. In March, the measure comes from a 3-item battery asking yes-or-no questions about whether subjects supported the cancellation of events, quarantines for infected individuals, and increasing spending with public healthcare during the pandemic. In April and June, two items asked about support for lockdown

3. The analyses of survey data were conducted with Stata 13.1.

4. The March survey included an experimental design prior to some of the dependent variables used here. Therefore, the analyses of the paper use 505 respondents that were not treated in the experiment.

5. See appendix for descriptive statistics about the sample.

6. See appendix for information about question wording. 
policies and for how long businesses should be closed during the pandemic ${ }^{7}$. The average score on the 0-1 scale drops from .94 in March to .74 in April and June. The final dependent variable about acceptance of Bolsonaro's economic frame to the pandemic comes from a question asked in April and June about whether respondents were more fearful of the economic or health consequences of the outbreak.

The measure of support for Bolsonaro comes from four different items. The first were about the President's job approval and whether his job was better or worse than expected. The other two questions were about their vote choice in the second round of the 2018 election and their vote intention if the 2022 elections. The latter were coded so that mentions to Bolsonaro were equal 1, mentions to his main opponent in 2018 (Fernando Haddad from the Workers' Party) were equal 0 , and other responses (absences and null/blank votes) were equal to .5. Using multiple measures provides many advantages in comparison to the single standard question of Presidential approval, such as higher reliability and variance that is less affected by short-term factors that can affect approval ${ }^{8}$. The final scale consists of the average across items, with higher values indicating higher support for Bolsonaro.

The measure of media choice comes from a multiple-choice item asking respondents about the type of news sources that they consider to be the most trustworthy. The response options included television, online websites or portals, social media, radio, magazines, and newspapers. The goal of this variable is to distinguish between low and high-choice media environments. In low-choice environments, people's political predispositions have a weak influence on their exposure to content, that is, they have more difficulty selecting content that fits their preferences. In high-choice environments, political predispositions drive exposure to content. In this sense, the option "news from TV" provides a low-choice environment, since mainstream media in Brazil is highly concentrated in a few networks that tend to provide overlapping content, particularly during the pandemic (Porto, 2012) ${ }^{9}$. We treat "news from online portals and websites" and "news from social media" as higher-choice environments. In both cases, while it is possible that individuals select mainstream news sources while consuming news in those environments, their key characteristic is that they allow news consumers to have more choice with respect to the content they are exposed to. While some individuals with preference

7. The Cronbach's Alpha for the 3-item scale in March is .73. The polychoric correlation between the two items used in April and June is .76 and .87 , respectively.

8. The Cronbach's Alpha for the scale is .87 in March, .86 in April, and .87 in June.

9. While cable TV is available for many Brazilians, the most popular cable news broadcasts such as Globonews and Record News are associated with mainstream TV networks (Rede Globo and Rede Record, respectively). 
for online environments can choose to view news from a TV channel's portal or Facebook page, others can rely on the same environment to consume news from pages that are explicitly aligned with political groups and often spread misinformation, such as Brasil Paralelo and Terça Livre. There is no equivalent to Brasil Paralelo and Terça Livre on Brazilian TV, which justifies its distinction as a low-choice environment relative to online environments ${ }^{10}$. Therefore, for the purposes of the analyses presented below, the variable of media choice used here is divided in three main categories. We code online websites/portals and social media as a single category indicating that respondents trust a high-choice environment for news consumption. The second category includes TV as the primary low-choice environment, since it comprises the majority of responses in all three surveys. Since radio, magazines, and newspapers are more difficult options to categorize due to locallevel variation, and also because they display low rates of response (never higher than $10 \%$ combined), we combine them with "don't knows" as baseline category.

The percentages of respondents who declare preference for television are 51 percent in March, 37 in April, and 49 in June. With respect to preference for internet sources, 28 percent prefer it in March, 33 in April, and 34 in June. Given that some of these proportions vary considerably from one month to the next, one possible threat to the idea of media choice as an exogenous factor that affects political perceptions could be partisan/political sorting. In other words, it could be the case that some of the hypothesized differences observed between March and the following months are due to respondents switching from one media to another based on the news content that they prefer. While that is possible, the relationships between media choice and several other variables, including support for Bolsonaro, do not change over time ${ }^{11}$. This indicates that, while the proportion of responses for each media choice category varies over time, the groups do not change systematically in their composition.

The control variables in the analyses of the next section are age (in years), left-right ideological placement, religion (indicators for Catholic and Evangelical), income, sex, and region of the country ${ }^{12}$. All control variables are also recoded to range between 0 and 1 .

10. Moreover, running the main analyses of the next section with "online portals and websites" separated from "social media" indicates that they are not statistically distinguishable from each other, while being very different from TV in their relationship with support for Bolsonaro and opinions. See appendix for results.

11. See online appendix for multinomial probit models of the correlates of media choice.

12. The rounds of surveys used here did not include education, which is a major limitation in the analysis. 


\section{RESULTS}

Figure 1 shows the predicted levels of concern about the virus and support for mitigation measures over time. The estimates are based on ordinary least squares (OLS) models that specify an interaction between support for Bolsonaro and media choice, while controlling for the variables discussed in the previous section. The graphs omit the estimates for respondents who chose other media sources or gave "don't know" answers. ${ }^{13}$ The expectation from Hypothesis 1 is that views on the outbreak are not polarized in March based on support for Bolsonaro or preferred media source. This is because Bolsonaro had not yet explicitly campaigned to trivialize the virus and undermine mitigation efforts. The expectations from $\mathrm{Hy}-$ potheses 2 are that views are polarized in April and June, with Bolsonaristas less concerned and less supportive of mitigation efforts, a process that would occur primarily among respondents who prefer to consume news online.

The results from Figure 1 support Hypotheses 1 and 2. The top graphs show that opinions about the outbreak and mitigation measures were overwhelmingly cooperative in March, regardless of media choice and support for Bolsonaro. After Bolsonaro's denialist escalation, the surveys from April and June show that his supporters become considerably less concerned about the virus and less supportive of mitigation measures. Moreover, polarization is more pronounced among respond ents who consider the online environment to have the most trustworthy news sources. Notably, the graphs also show growth in polarization among TV respondents. This could be due to spillover effects, since respondents who trust television could still consume information online, or due to Bolsonaro's stances being covered on TV, although with a predominantly critical tone. Nonetheless, the patterns show that the online environment explains a large portion of the politicization of the pandemic.

Hypothesis 3 states that respondents from online environments and Bolsonaro supporters are more likely to endorse the economic frame provided by Bolsonaro in his attempt to downplay the health-related threats of the virus. In order to test that, Figures 2 and 3 show the predicted probabilities of respondents considering the economic consequences of the outbreak to be more concerning than the health-related consequences in April and June, when the question was asked. The estimates are based on probit models, since the dependent variable is a binary response. The estimates come from additive models and show the direct effects of media choice and support for Bolsonaro on the dependent variable. Specifying an interaction term between the two variables does not yield statistically significant results, which indicates that the economic frame distinguishes supporters from non-supporters both online and offline.

13. Among respondents who choose "other" as media choice in March, support for Bolsonaro increases concern and support for measures. In April and June, the relationship is the negative. See online appendix. 
Figure 1. Predicted values (OLS) of concern about Covid-19 and support for measures by Bolsonaro support, media choice, and month. Year 2020

\section{March}

Concern About Covid-19


Support for Measures

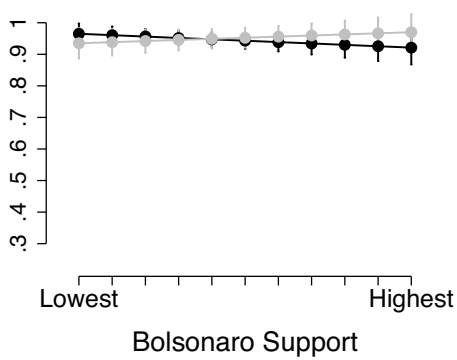

\section{April}

Concern About Covid-19

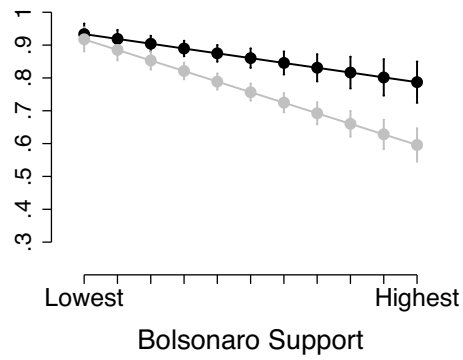

Support for Measures

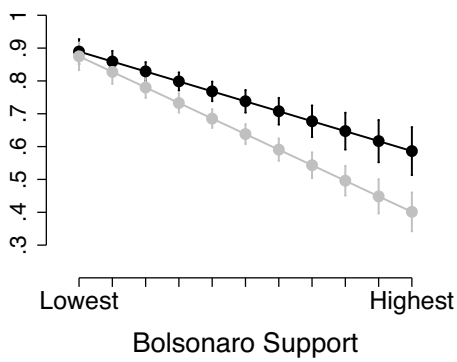

\section{June}

Concern About Covid-19

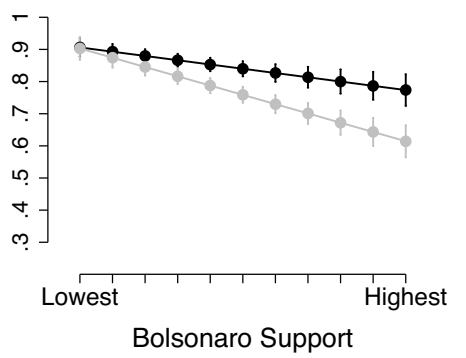

Support for Measures

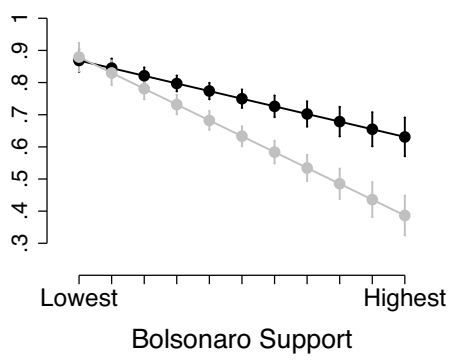

Source: authors' elaboration. Black line is TV, gray line is Internet. 
Figure 2. Predicted probabilities (Probit) of acceptance of economic frame by media choice and month

Acceptance of Economic Frame
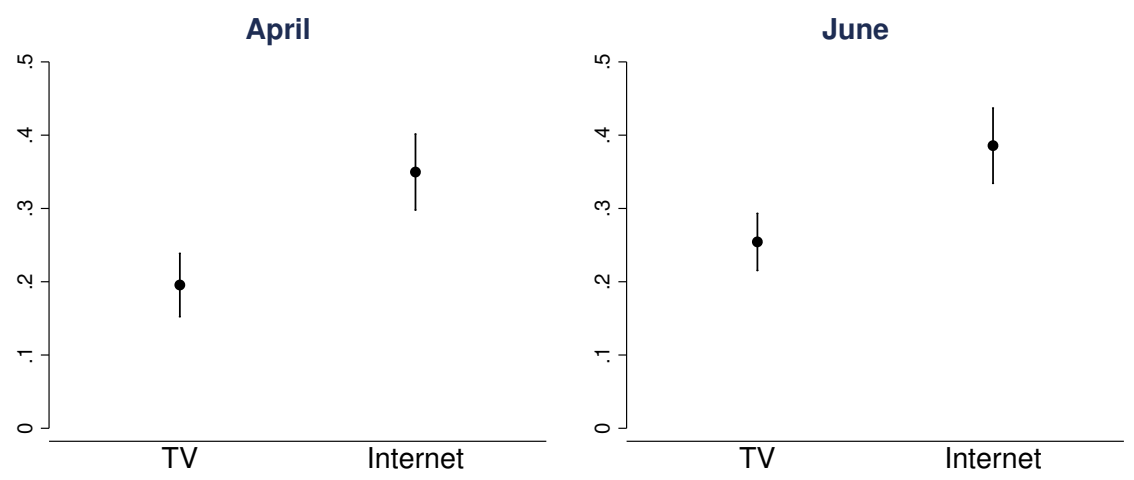

Source: authors' elaboration.

Figure 3. Predicted probabilities (Probit) of acceptance of economic frame by Bolsonaro support and month

Acceptance of Economic Frame

April

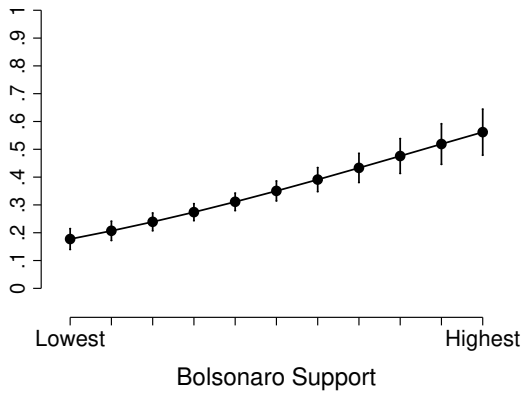

June

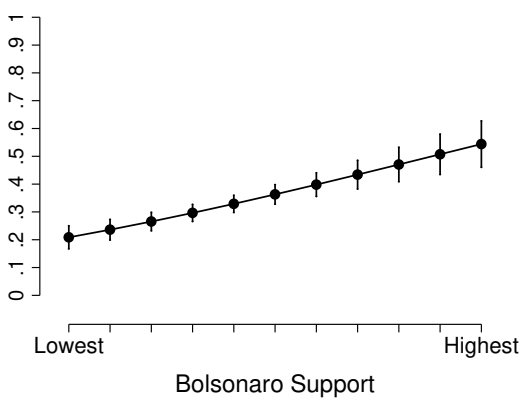

Source: authors' elaboration.

The results in Figures 2 and 3 support Hypothesis 3. Respondents who prefer to consume news online are considerably more likely to consider the economic consequences of the outbreak more concerning than its health consequences, according to Figure 2 for April and June. Figure 3 shows that Bolsonaro supporters are more likely to endorse the economic framing to the outbreak both in April and June. These results also shed light on some noticeable patterns observed in Figure 1. As that figure shows, the degree of polarization in concern about the virus is 
smaller compared to polarization in views about large-scale mitigation measures. The results from Figures 2 and 3 indicate that, even though the levels of concern remained relatively high after March, they likely changed in meaning over time. It is likely that many Bolsonaristas remained personally concerned about the virus after March, but replaced health with economic considerations in their sociotropic reasoning about the pandemic due to Bolsonaro's influence. Consequently, while still concerned, they became considerably less supportive of mitigation efforts based on the President's view that those would hurt the economy.

\section{CONCLUSION}

Brazil is among the countries most affected by the Covid-19 pandemic both in terms of contamination and deaths, while facing the collapse of its healthcare system and a long-term economic recession. One of the key elements to understand the pandemic in Brazil are the higher levels of polarization over the issue in comparison to other countries around the world (IPSOS, 2020). Since near unanimous cooperation in large-scale mitigation efforts is crucial for overcoming epidemics (Salathé and Bonhoeffer, 2008; Reluga, 2010; Sahneh et al., 2012), it is likely that lower levels of cooperation in Brazil help explain the failure of the country to address the issue.

However, Brazil was not always divided about the pandemic. As we show, public opinion did not initially perceive the issue through politicized lens, as opinions were overwhelmingly cooperative and not correlated with political preferences in March. According to extant scholarship, President Jair Bolsonaro was largely responsible for fueling defection and polarization about the issue over time. The President's denialist stance, expressed more openly after his March 24th nationally televised address, turned his sup-porters against the broad consensus about the gravity of the issue and what to do about it (Ajzenman et al., 2020; Calvo and Ventura, 2020). Our paper contributes to this scholarship by showing how Bolsonaro defied the existing consensus, which included mainstream media. As we show, Bolsonaro was able to spread his message mainly through online media environments, where individuals are better able to choose the news content that matches their political preferences.

Our findings have two main implications related to the growth of online environments in the process of issue formation in public opinion. First, while mainstream media outlets do not always converge on their coverage of current events, our findings indicate that any degree of convergence can potentially be challenged by the spread of divergent information in online environments. Evidence suggests that social media clusters can undermine consensus even regarding more stablished issues such as vaccination and climate change (McKee and Diethelm, 2010; 
Kata, 2012). As an extreme and highly salient case, the Covid-19 pandemic in Brazil provides a clear example in which online environments hosted and reproduced a level of dissent that was not observed in other media environments and institutions in that context.

Finally, the findings highlight important features of populist leadership in times in which individuals have higher levels of media choice than ever. While disagreement about the pandemic in Brazil was reproduced and fostered in online environments, one of the main sources of dissent was a populist leader with specific political interests. The findings suggest that there may be threats to accountability in informational environments in which populists can reach audiences and maintain their support through means that are not mediated by other institutions. Hence, media choice in online environments can be used by populists in attempts to distract voters about wrongdoings and undermine consent on issues that require institutional cooperation and trust.

\section{REFERENCES}

Ajzenman, N., Cavalcanti, T., \& Da Mata, D. (2020). More than Words: Leaders' Speech and Risky Behavior During a Pandemic. Available at: http://dx.doi.org/10.2139/ssrn.3582908.

Baekkeskov, E. and Rubin, O. (2014). Why pandemic response is unique: powerful experts and hands-off political leaders. Disaster Prevention and Management, 23(1), 81-93.

Bakshy, E., Messing, S., \& Adamic, L. A. (2015). Exposure to ideologically diverse news and opinion on Facebook. Science, 348(6239), 1130-1132.

Barberá, P., Jost, J. T., Nagler, J., Tucker, J. A., \& Bonneau, R. (2015). Tweeting From Left to Right: Is Online Political Communication More Than an Echo Chamber? Psychological Science, 26(10), 1531-1542.

Bennett, W. L., \& lyengar, S. (2008). A New Era of Minimal Effects? the Changing Foundations of Political Communication. Journal of Communication, 58, 707-731.

Betz, H.-G. (2019). Populist mobilization across time and space. In K. A. Hawkins, R. A. Carlin, L. Littvay, \& C. R. Kaltwasser (Eds.), The ideational approach to populism: concept, theory and analysis (pp. 181-201). New York: Routledge.

Boas, T. C. (2005). Television and Neopopulism in Latin America: Media Effects in Brazil and Peru. Latin American Research Review, 40(2), 27-49.

Bol, D., Giani, M., Blais, A., \& Loewen, P. J. (forthcoming, 2020). The effect of COVID-19 lockdowns on political support: Some good news for democracy? European Journal of Political Research.

Calvo, E., \& Ventura, T. (forthcoming, 2020). Will I get COVID-19? partisanship, Social Media Frames, and Perceptions of Health Risk in Brazil. Latin American Politics \& Society.

Cohen, J. E. (2015). Presidential Leadership of Public Opinion: An Embedded Survey Experiment. Political Communication, 32(3), 345-355.

Croda, J., de Oliveira, W. K., Frutuoso, R. L., Mandetta, L. H., da Silva, D. C. B., Brito-Souza, J. D., Monteiro, W. M., and aes Lacerda, M. V. G. (2020). COVID-19 in Brazil: advantages of 
a socialized uni ed health system and preparation to contain cases. Journal of the Brazilian Society of Tropical Medicine, 53(e20200167), 1-6.

Datafolha (2020a). Opinião sobre a pandemia de coronavírus: conhecimento e meios de informaçãp. Retrieved from: http://datafolha.folha.uol.com.br/opiniaopublica/2020/04/ 1988655-78-se-consideram-bem-informados-sobre-coronavirus.shtml.

Datafolha (2020b). Opiniões sobre a pandemia coronavírus. Retrieved from: http://datafolha.folha.uol.com.br/opiniaopublica/2020/05/1988729-60-sao-favoraveis-a-fechamento-total-para-conter-coronavirus.shtml.

Deutsche Welle. (2020, March 7). Coronavírus: Bolsonaro diz que não há motivo para pânico. Deutsche Welle. https://www.dw.com/pt-br/coronavrus-bolsonaro-diz-que-no-hmotivo-para-pnico/a-52675458.

do Amaral, O. E. (2020). The Victory of Jair Bolsonaro According to the Brazilian Electoral Study of 2018. Brazilian Political Science Review, 14(1), 1-13.

Duque, D., \& Smith, A. E. (2019). The Establishment Upside Down: A Year of Change in Brazil. Revista de Ciencia Política, 39(2), 165-189.

Eisenhammer, S., \& Spring, J. (2020, March 24). Bolsonaro urges Brazilians back to work, dismisses coronavirus 'hysteria'. Reuters. https://www.reuters.com/article/us-healthcoronavirus-brazil/bolsonaro-urges-brazilians-back-to-work-dismisses-coronavirushysteria-idUSKBN21B2H2/.

Fraile, M., \& lyengar, S. (2014). Not all news sources are equally informative: A cross- national analysis of political knowledge in europe. International Journal of Press/Politics, 19(3), 275-294.

G1. (2020, March 9). Bolsonaro diz que 'poder destruidor' do coronavírus 'está sendo superdimensionado'. G1. https://g1.globo.com/bemestar/coronavirus/noticia/2020/03/09/ bolsonaro-diz-que-poder-destruidor-do-coronavirus-esta-sendo-superdimensionado. ghtml.

Galhardi, C. P., Freire, N. P., de Souza Minayo, M. C., \& Fagundes, M. C. M. (2020). Fact or Fake? an analysis of disinformation regarding the Covid-19 pandemic in Brazil. Ciência \& Saúde Coletiva, 25, 4201-4210.

Impactos da pandemia de COVID-19 na televisão brasileira. (2021, January 8). In Wikipedia. Retrieved from https://pt.wikipedia.org/wiki/Impactos_da_pandemia_de_ COVID-19_na_televisão_brasileira.

IPSOS (2020). What Worries the World? Retrieved from: https://www.ipsos.com/sites/ default/files/ct/news/documents/2020-04/what-worries-the-world-april-2020-ipsos. pdf.

Kata, A. (2012). Anti-vaccine activists, web 2.0, and the postmodern paradigm - an overview of tactics and tropes used online by the anti-vaccination movement. Vaccine, 30(25), 3778-3789.

Machado, C., Kira, B., Narayanan, V., Kollanyi, B., \& Howard, P. N. (2019). A study of misinformation in Whatsapp groups with a focus on the Brazilian presidential elections. In Proceedings of The Web Conference, WWW'19.

Manchetômetro. (2020, April 22). Boletim M - A Cobertura do Coronavírus. Retrieved from http://www.manchetometro.com.br/index.php/publicacoes/boletim-m/2020/04/22/ boletim-m-a-cobertura-do-coronavirus/. 
Massuchin, M. G., Mitozo, I. B., \& de Carvalho, F. C. (2017). Eleições e debate político on-line em 2014: os comentários no Facebook do jornal O Estado de São Paulo. Revista Brasileira de Ciência Política, 23, 295-320.

Mclntyre, L. (2018). Post-truth. Cambridge: MIT Press.

McKee, M., \& Diethelm, P. (2010). How the growth of denialism undermines public health. The BJM, 341, 1-6.

Mendonça, R. F., \& Amaral, E. F. L. (2016). Racionalidade online: provimento de razões em discussões virtuais. Opinião Pública, 22(2), 418-445.

Mitozo, I. B., Massuchin, M. G., \& de Carvalho, F. C. (2017). Debate políttico-eleitoral no Facebook: os comentários do público em posts jornalísticos na eleição presidencial de 2014. Opinião Pública, 23(2), 459-484.

Mondak, J. J. (1993). Source cues and policy approval: The cognitive dynamics of public support for the Reagan agenda. American Journal of Political Science, 37(1), 186-212.

Mounk, Y. (2018). The people vs. democracy: Why our freedom is in danger and how to save it. Cambridge: Harvard University Press.

Mudde, C., \& Rovira Kaltwasser, C. (2017). Populism: A Very Short Introduction. Oxford: Oxford University Press.

Mundim, P. S. (2012). Imprensa e voto nas eleições presidenciais brasileiras de 2002 e 2006. Revista de Sociologia e Política, 20(41), 123-147.

Porto, M. (2010). The Changing Landscape of Brazil's News Media. In D. A. Levy and R. K. Nielsen (Eds.), The Changing Business of Journalism and its Implications for Democracy (pp. 107-124). Oxford: Oxford University Press.

Porto, M. (2012). Media Power and Democratization in Brazil: TV Globo and the Dilemmas of Political Accountability. New York: Routledge.

Prior, M. (2005). News vs. Entertainment: How Increasing Media Choice Widens Gaps in Political Knowledge and Turnout. American Journal of Political Science, 49(3), 577-592.

Ragsdale, L. (1984). The politics of presidential speechmaking, 1949-1980. The American Political Science Review, 78(4), 971-984.

Recuero, R., \& Soares, F. (2020). O Discurso Desinformativo sobre a Cura do COVID-19 no Twitter. E-Compós.

Reluga, T. C. (2010). Game theory of social distancing in response to an epidemic. PLos Computational Biology, 6(5), 1-9.

Rennó, L. (Forthcoming, 2020). The Bolsonaro Voter: Issue Positions and Vote Choice in the 2018 Brazilian Presidential Elections. Latin American Politics \& Society.

Resende, G., Melo, P., Reis, J. C. S., Vasconcelos, M., Almeida, J., \& Benevenuto, F. (2019). Analyzing Textual (Mis)information Shared in WhatsApp Groups. In Proceedings of the ACM Conference on Web Science, WebSci'19.

Ricard, J., \& Medeiros, J. (2020). Using misinformation as a political weapon: COVID- 19 and Bolsonaro in Brazil. The Harvard Kennedy School Misinformation Review, 1(2), 1-7.

Rocha, M. M., de Almeida, P., \& Corrêa, I. (2020). Os Governos Municipais Frente ao Coronavirus: Um Balano Provisório. Research Report: Núcleo de Estudos sobre Política Local (UFJF).

Rossini, P., Stromer-Galley, J., Erica Anita Baptista, \& Vanessa Veiga de Oliveira (2020). Dysfunctional information sharing on Whatsapp and Facebook: The role of political talk, cross-cutting exposure and social corrections. new media \& society, 1-22. 
Rottinghaus, B. (2009). Strategic leaders: Determining successful presidential opinion leadership tactics through public appeals. Political Communication, 26(3), 296-316.

Rovira Kaltwasser, C. (2017). Populism and the Question of How to Respond to it. In R. Kaltwasser, C., Taggart, P., Espejo, P. O., \& Ostiguy, P. (Eds.), The Oxford Handbook of Populism (pp. 489-507). Oxford: Oxford University Press.

Sahneh, F. D., Chowdhury, F. N., \& Scoglio, C. M. (2012). On the existence of a threshold for preventive behavioral responses to suppress epidemic spreading. Scientific Reports, 2(632), 1-8.

Salathé, M., \& Bonhoeffer, S. (2008). The effect of opinion clustering on disease out- breaks. Journal of the Royal Society Interface, 5(29), 1505-1508.

Silva, C., \& Suzart, W. (2020). Reflexivity and media: the covid-19 and local development in Brazil. International Journal of Development Research, 10(08), 39434-39437.

Storopoli, J., da Silva Neto, W. L. B., \& Mesch, G. S. (2020). Confidence in social institutions, perceived vulnerability and the adoption of recommended protective behaviors in brazil during the COVID-19 pandemic. Social Science and Medicine, 265, 1-7.

Stroud, N. J. (2008). Media use and political predispositions: Revisiting the concept of selective exposure. Political Behavior, 30, 341-366.

Stroud, N. J. (2010). Polarization and Partisan Selective Exposure. Journal of Communication, 60, 556-576.

Tamaki, E. R., \& Fuks, M. (2020). Populism in Brazil's 2018 General Elections: An Analyses of Bolsonaro's Campaign Speeches. Lua Nova, 109, 103-127.

Vieira, M. C., \& Matos, C. (2020, June 19). A retórica de Bolsonaro: o que revelam os discursos na pandemia. Veja. Retrieved from: https://veja.abril.com.br/politica/aretorica-de-bolsonaro-o-que-revelam-os-discursos-na-pandemia/

Waisbord, S., \& Amado, A. (2017). Populist communication by digital means: presidential Twitter in Latin America. Information, Communication \& Society, 20(9), 1330-1346.

Waldron, T. (2020, March 12). Bolsonaro Blames the Medias as Coronavirus Worsens in Brazil. Huffpost. https://www.huffpost.com/entry/jair-bolsonaro-coronavirus-brazil-tr ump_n_5e6a443cc5b6747ef1186cb3.

Weyland, K. (1998). The Politics of Corruption in Latin America. Journal of Democracy, 9(2).

Weyland, K. (2001). Clarifying a Contested Concept: Populism in the Study of Latin American Politics. Comparative Politics, 34(1), 1-22. 
